\title{
Exploration of alginate hydrogel/nano zinc oxide composite bandages for infected wounds [Corrigendum]
}

Mohandas A, Kumar PT S, Raja B, et al. Int J Nanomedicine. 2015;10(Suppl 1):53-66.

The authors have advised that Figure $8 \mathrm{~B}$ and $\mathrm{C}$ (page 62) were incorrect in the original manuscript, as the Alginate control group is inadvertently repeated in the Alginate $+0.1 \%$ nZnO group. Due to this mistake they have repeated the entire cell attachment studies using DAPI. The authors have confirmed that this does not in any way affect the conclusions from Figure $8 \mathrm{~B}$ and $\mathrm{C}$, and that it is not going to affect the overall conclusion of this published paper. They apologize for any inconvenience. The correct version of Figure 8 is presented below.
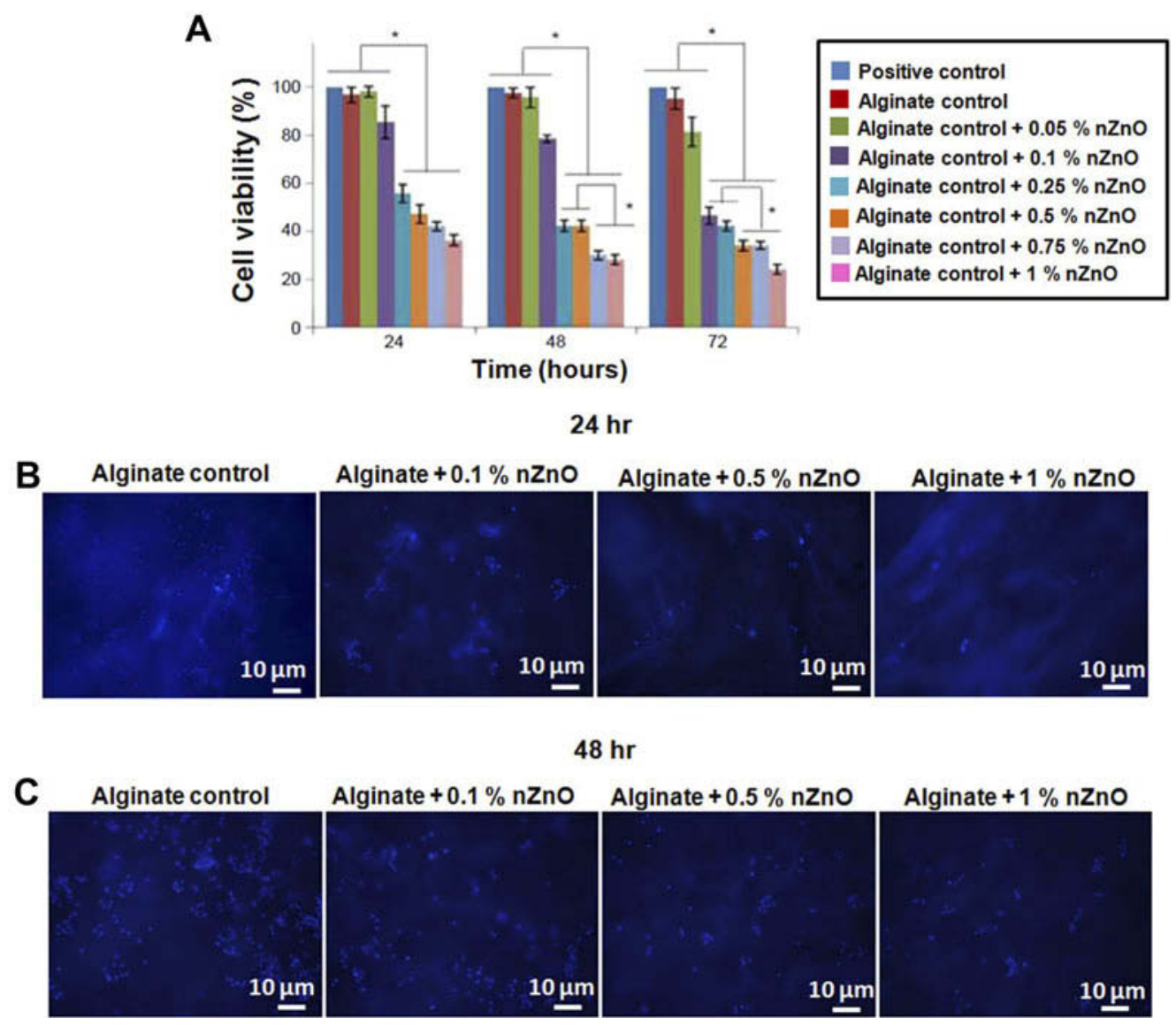

Figure 8 Evaluation of cytocompatability of alginate hydrogel/nZnO composite bandages. (A) Cell viability evaluation of HDF cells using Alamar blue assay. Student's t-test was performed and P-values $<0.05$ were considered significant. (B and C) DAPI stained fluorescence microscopic images of HDF cells attached onto the composite bandages. *Indicates significant difference compared the control. Scale bar denotes $10 \mu \mathrm{m}$.

Abbreviations: HDF, human dermal fibroblast; DAPI, 4',6-diamidino-2-phenylindole; $\mathrm{nZnO}$, zinc oxide nanoparticles; hr, hours. 


\section{Publish your work in this journal}

The International Journal of Nanomedicine is an international, peerreviewed journal focusing on the application of nanotechnology in diagnostics, therapeutics, and drug delivery systems throughout the biomedical field. This journal is indexed on PubMed Central,

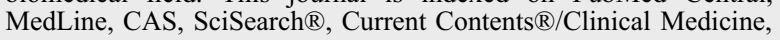

Journal Citation Reports/Science Edition, EMBase, Scopus and the Elsevier Bibliographic databases. The manuscript management system is completely online and includes a very quick and fair peer-review system, which is all easy to use. Visit http://www.dovepress.com/ testimonials.php to read real quotes from published authors. 